\title{
Advent of Spring
}

\author{
BY ELIZABETH B. FLOCK
}

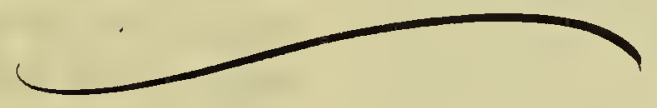

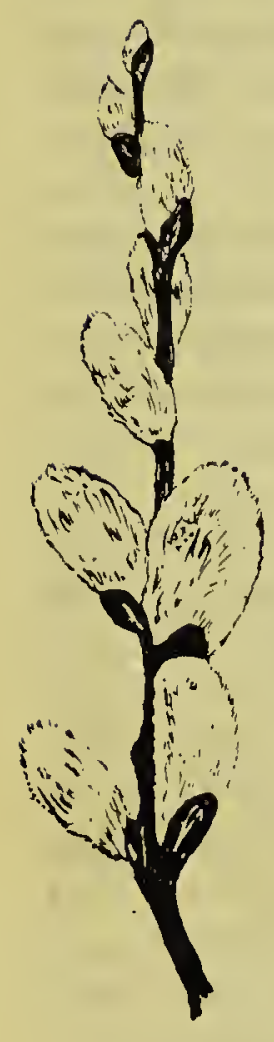

"We embark each year on the sea of winter, with unquestioning faith that on its other shore spring awaits us, once more to shake the violets from her lap. When, in March, that shore looms in the distance, we feel the joy of travelers in sight of their native land. "There may be rough seas, and March winds are blustery, but there in sight, nevertheless, is that faint outline on the horizon..'

Here on the prauries we know the first horned larks do not mean spring, but they give a lift to the spirits after our long winter. . During this time it is well to review nature books so as to be prepared for what is to come. A further period of waiting is necessary before a few more hardy birds arrive and we know another joyous season is upon us.

Even crows as they flap over two or three at a time are a welcome sight. Juncos and tree sparrows bathe in pools of snow water or trill their sweet songs on the frosty air. A kill deer returns to sit disconsolately on the ice bordering the lake as though wondering why he had been in such a hurry. Robins are more interested in a meal than song at first. No one can fail to agree that "a flock of wild geese on the wing is no less than an inspiration. When that strong-voiced, stout-hearted company of pioneers pass overhead, our thoughts ascend and sail with them over the roofs of the world. As band after band come into the field of vision - minute glittering specks in the distant blue to cross the golden sea of the sunset and disappear in the northern twilight, their faint melodious honk is an Orp han strain drawing irresistibly."

Nor are birds the sole object of outings, As the soil grows warmer, plant life begins with the first prairie crocus in bloom. Then follow in close succession wild parsleys, moss phlox and a mounting host of others, each a gem of beauty if viewed attentively. The ephemeral display of blossoms on forest trees is a treat to the beholder. There samples of flower evolution from primitive forms can be seen each year in the conifer blossoms with staminate and pistillate separate on each tree. The willows date back to an early era also, producing these flowers on separate trees, while theelms have perfect ones, but no petals. Stamens and pistils alone make the lacy pattern.

The wind aids in cross-pollinating the conifers and willows, but bees in hordes buzz about the pollen-bearing flowers in their rush to gather it for the hive. Butterflies, like the mourning cloak that lay dormant all winter, appear somewhat bedraggled in appearance. Others are just emerging from their cocoons. The warm sun of spring brings out many forms of insect life.

Those who follow Nature's trail never tire of this annual event of returning life. It is a simple pleasure open to all of any age. " Over and above a healthy curiosity, or any scientific acquaintance, it is the companionship of the woods and fields which counts a real friendship for birds and bees and flowers." 